\title{
Miocene igneous activity in the Northern Subbasin, offshore Senegal, NW Africa
}

\author{
Dorthe Møller Hansen ${ }^{\mathrm{a}, *}$, Jonathan Redfern ${ }^{\mathrm{a}}$, Francesco Federici ${ }^{\mathrm{b}}$, \\ Davide di Biase ${ }^{\mathrm{b}}$, Giuseppe Bertozzi ${ }^{\mathrm{b}}$ \\ ${ }^{a}$ North Africa Research Group, School of Earth, Atmospheric and Environmental Sciences, University of Manchester, \\ Williamson Building, Oxford Road, Manchester M13 9PL, UK \\ ${ }^{\mathrm{b}}$ Edison International, Foro Buonaparte 31, 20121 Milan, Italy
}

Received 15 December 2006; received in revised form 3 April 2007; accepted 8 April 2007

\begin{abstract}
More than 70 enigmatic discordant seismic anomalies of limited lateral extent, associated with eye-shaped structures and folds, have been imaged on 2D seismic data from the offshore Northern Subbasin of the Senegal Basin, NW Africa. In this paper we define their distribution, characterise their morphology and compare them to similar features imaged by seismic data along the NE Atlantic Margin that have been demonstrated to be igneous sills, hydrothermal vents and intrusion-related forced folds. We propose that the Cretaceous and Paleogene strata in the northernmost part of the offshore Northern Subbasin were heavily intruded by igneous sills during the Miocene. The proposed timing of intrusion is coincident with that previously suggested for the development of the Cayar Seamount located $100 \mathrm{~km}$ NNW of Dakar and onshore volcanism in the Cap-Vert area near Dakar and in the Cape-Verde Islands. This stage of Miocene igneous activity is interpreted to be closely associated with the coeval collision between Africa and Europe. The interpreted igneous sills give rise to an unexpected "soft" seismic response. The preferred explanation for the "soft" appearance of the sills is that the majority of sills are thin $(<90 \mathrm{~m})$ and hence their seismic appearance is affected by interference between the acoustic response from the top and base of the sills. The identification of shallow-level igneous intrusives in the offshore Northern Subbasin has important implications for hydrocarbon exploration in the Senegal Basin and possibly more broadly for hydrocarbon exploration in Atlantic basins offshore NW Africa.
\end{abstract}

(C) 2007 Elsevier Ltd. All rights reserved.

Keywords: Senegal Basin; NW Africa; Igneous; Intrusion; Seismic; Hydrothermal vents; Forced folds

\section{Introduction}

The Senegal Basin (Fig. 1a) is the largest of the NW Africa Atlantic Basins covering an onshore area of approximately $340,000 \mathrm{~km}^{2}$ and an offshore area in excess of $100,000 \mathrm{~km}^{2}$ (Brownfield and Charpentier, 2003). The hydrocarbon potential of the basin is still poorly constrained, and although three possible petroleum systems have been proposed, only limited exploration activity has been undertaken to date (Brownfield and Charpentier, 2003). The Northern Subbasin, one of three subbasins of the Senegal Basin, is experiencing increased interest as hydrocarbon exploration moves towards higher risk deep-

\footnotetext{
*Corresponding author.

E-mail address: dorthe.hansen@manchester.ac.uk (D.M. Hansen).
}

water plays. Detailed interpretation of 2D seismic data from the Northern Subbasin (Fig. 1b) has revealed a number of previously unrecognised features within the Cretaceous and Paleogene interval (Fig. 2b). Most curious is the presence of numerous high amplitude discordant, commonly upward concave and cross-cutting reflections imaged within the Cretaceous sediments on seismic sections. Based on interpretation of $>70$ of these seismic anomalies they can be characterised as circular to slightly elongated bodies of limited lateral extent $(300 \mathrm{~m}-10 \mathrm{~km})$ and with vertical relief of up to $350 \mathrm{~m}$. They are often interconnected and distributed over an area $>3000 \mathrm{~km}^{2}$ within the Rufisque Profond Block (Fig. 1b).

High amplitude discordant seismic reflections hosted within sedimentary basin-fills may be interpreted as either erosional or intrusive (salt, clastic or igneous) in origin. 

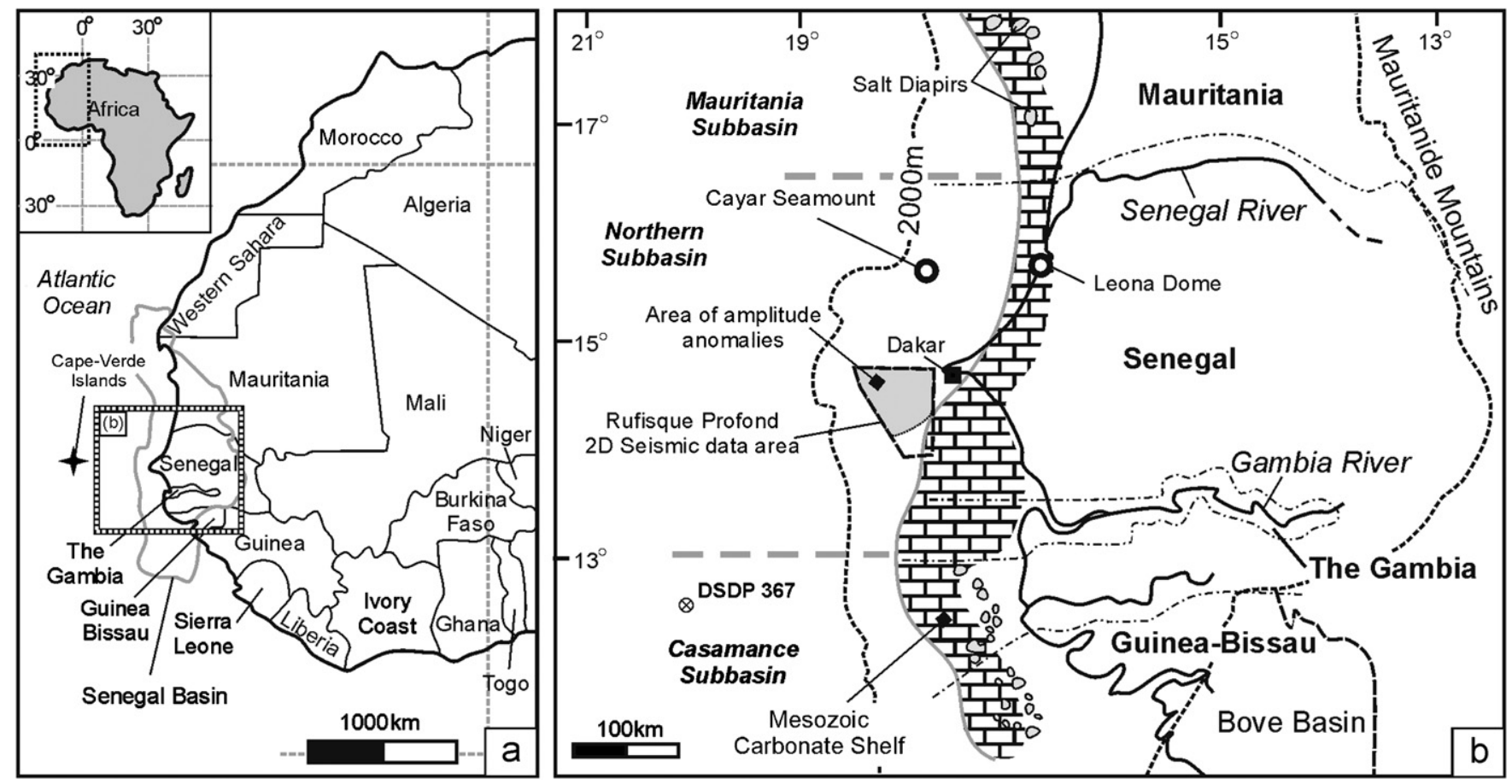

Fig. 1. (a) Location of the Senegal Basin, NW Africa. (b) Location map showing the three subbasins of the Senegal Basin (N $\rightarrow$ S): the Mauritanian Subbasin, the Northern Subbasin (focus of this study) and the Casamance Subbasin. The map also shows the outline of the Rufisque Profond 2D seismic data in which detailed mapping of high amplitude reflection anomalies has been carried out. Note the location of the Cayar Seamount approximately $100 \mathrm{~km} \mathrm{NNW}$ of Dakar and the DSDP 367 well located approximately $350 \mathrm{~km} \mathrm{SW}$ of Dakar. Both maps modified from Brownfield and Charpentier (2003).
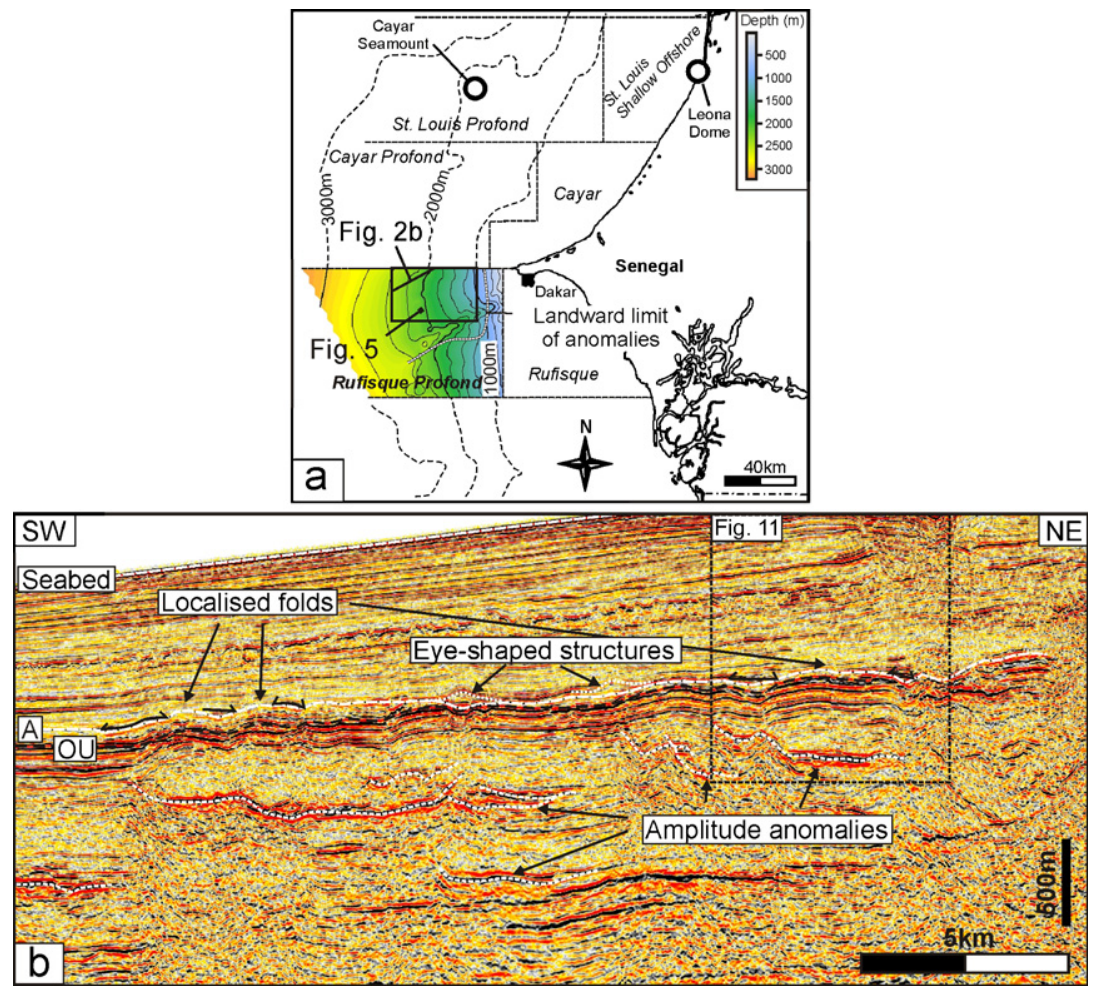

Fig. 2. (a) Seabed bathymetry in metres based on interpretation of the $2 \mathrm{D}$ seismic data (depth converted using a water velocity of $1500 \mathrm{~m} / \mathrm{s}$ ). The map shows the division of the offshore Senegal area into blocks. The landward extent of the high amplitude reflections is shown by a white dashed line. (b) $2 \mathrm{D}$ seismic section illustrating the seismic character of the enigmatic features: (1) amplitude anomalies, (2) "eye-shaped" structures and (3) localised folds, recognised within the northern part of the Rufisque Profond block. Horizon A has been mapped across the Rufisque Profond area as a reflection of opposite polarity to that of the seabed and with moderate to high amplitude. OU marks an Oligocene (-Early Miocene) unconformity correlated from the DSDP 367 well. 
In this paper we describe, in detail, the distribution and seismic character of the amplitude anomalies within the Northe Subbasin and consider the possible interpretations. We conclude that they are most like to be igneous intrusions. This interpretation is primarily based on the geometrical appearance of the anomalies and their clear similarity with dolerite sills imaged by seismic data along the NE Atlantic Margin (Smallwood and Maresh, 2002; Trude et al., 2003; Hansen et al., 2004; Thomson and Hutton, 2004; Planke et al., 2005; Hansen and Cartwright, 2006a). The interpretation is further supported by the spatial association of the interpreted igneous sills with eyeshaped mounds and fold structures (Fig. 2b), the equivalents of which are known from the NE Atlantic Igneous Province and interpreted as hydrothermal vents (Svensen et al., 2004; Planke et al., 2005; Hansen, 2006) and intrusion-related forced folds (Trude et al., 2003; Hansen and Cartwright, 2006b).

Evidence for Tertiary and Quaternary basic igneous activity is abundant at outcrops in the Cap-Vert area around Dakar in the form of intrusive bodies and tuff deposits (Bellion and Crevola, 1991; Liégeois et al., 2005). Offshore, the presence of igneous bodies has been inferred in the northern part of the Northern Subbasin from gravity and magnetic data sets (Bellion and Crevola, 1991). Anomalous gravity and magnetic values are recorded in areas immediately offshore Dakar, around the Cayar Seamount and around the Leone Dome (Fig. 1b). Further offshore, volcanic activity in the Cape-Verde Islands, located approximately $500 \mathrm{~km}$ west of Dakar (Fig. 1a) (Mitchell et al., 1983; Patriat and Labails, 2006). This paper provides further insights into the occurrence of igneous activity offshore Senegal and its origin and implications for hydrocarbon exploration are discussed.

\section{Geological context}

The study area is located in the offshore part of the Northern Subbasin of the Senegal Basin along the northwestern Atlantic Margin of Africa (Fig. 1). The Senegal Basin is classed as an Atlantic-type passive margin of Middle Jurassic to Holocene age (Brownfield and Charpentier, 2003; Liégeois et al., 2005). The Northern Subbasin is delimited by $\mathrm{E}-\mathrm{W}$ trending geographical boundaries and situated between the Gambia River to the south and the Senegal River to the north (Fig. 1b).

The evolution of the Senegal Basin can be divided into three stages (Brownfield and Charpentier, 2003): (1) pre-rift (Upper Proterozoic to Paleozoic), (2) syn-rift (PermianTriassic) and (3) post-rift (Middle Jurassic-Holocene). The Pre-rift section consists of Precambrian- to Devonian-age rocks that crop out in the Bove Basin of southern Senegal and Guinea. The most complete pre-rift section has been drilled in the Casamance Subbasin where Ordovician sandstones, Silurian shales and Devonian sandstones and shales were penetrated. The syn-rift section comprises a Triassic clastic section, overlain by a ca. $2000 \mathrm{~m}$ thick succession of Triassic and Early Jurassic evaporites (Fig. 3). Salt diapirism occurs in the Mauritanian and Casamance Subbasins, but salt has not been recognised in the Northern Subbasin (Fig. 1b). The post-rift section consists of Middle Jurassic to Holocene rocks and the section thickens east to west across the Senegal Basin. A thick $(>2000 \mathrm{~m})$ carbonate-rock shelf of Middle-Late Jurassic to Neocomian age forms the lower unit of the post-rift section. In the Northern Subbasin (Fig. 3) carbonate deposition continued during the Aptian and Albian. The Cenomanian section is dominated by marine shales interbedded with some marginal marine sands and minor carbonate banks and reefs. Maximum transgression occurred during the Turonian. Black shales of this age range between 50 and $150 \mathrm{~m}$ in thickness. A subsequent major marine regression during the Senonian culminated with the widespread deposition of thick sandstones in the Maastrichtian.

Tertiary marine shales and carbonates unconformably overlie the Upper Cretaceous section. Carbonates were deposited during the Eocene in both the Northern Subbasin and the more southerly Casamance Subbasin (Brownfield and Charpentier, 2003). In the Casmance Subbasin carbonates were also deposited in the Oligocene. However, in the DSDP 367 well located approximately $350 \mathrm{~km}$ south-west of Dakar in the northern Casmance Subbasin, the Oligocene section is missing and the Eocene is separated from (Lower) Miocene deposits by an erosional unconformity (Oligocene unconformity, OU). The Oligocene is generally considered to be missing from the Northern Subbasin and the Southern part of the Mauritanian Subbasin (Fig. 3; Brownfield and Charpentier, 2003).

Three main stages of igneous activity (Triassic-Jurassic, mid-late Cretaceous, and Tertiary-Quaternary) have been recognised onshore and offshore Senegal and are described by Bellion and Crevola (1991). Scattered Oligocene to Quaternary volcanic rocks outcrop around Dakar (Cap-Vert volcanic centre) extending approximately $100 \mathrm{~km}$ eastwards and covering an onshore area of $>3000 \mathrm{~km}^{2}$. Two other volcanic centres are also reported; the Cretaceous Leona Dome located approximately $120 \mathrm{~km}$ along the coast northeast of Dakar (Fig. 1b) and the dominantly Miocene aged Cayar Seamount located offshore approximately $100 \mathrm{~km}$ NNW of Dakar (Figs. 1b and 2a). Further offshore in the Cape-Verde Islands (Fig. 1a), a late phase of Miocene volcanism in the form of sheet intrusions, lavas and non-marine volcaniclastic sediments, has been dated through $\mathrm{K} / \mathrm{Ar}$ and $\mathrm{Ar} / \mathrm{Ar}$ studies at 20-7 My (Mitchell et al., 1983; Patriat and Labails, 2006) with some evidence indicating activity as far back as $40-50 \mathrm{Ma}$ (Courtney \& White, 1986).

The Senegal Province is under-explored considering its large size and current hydrocarbon production is limited to gas and minor amounts of oil (Brownfield and Charpentier, 2003). The primary source rocks in the Senegal Basin are the Cenomanian-Turonian marine shales. The main reservoir units are the Upper Cretaceous sandstones and 


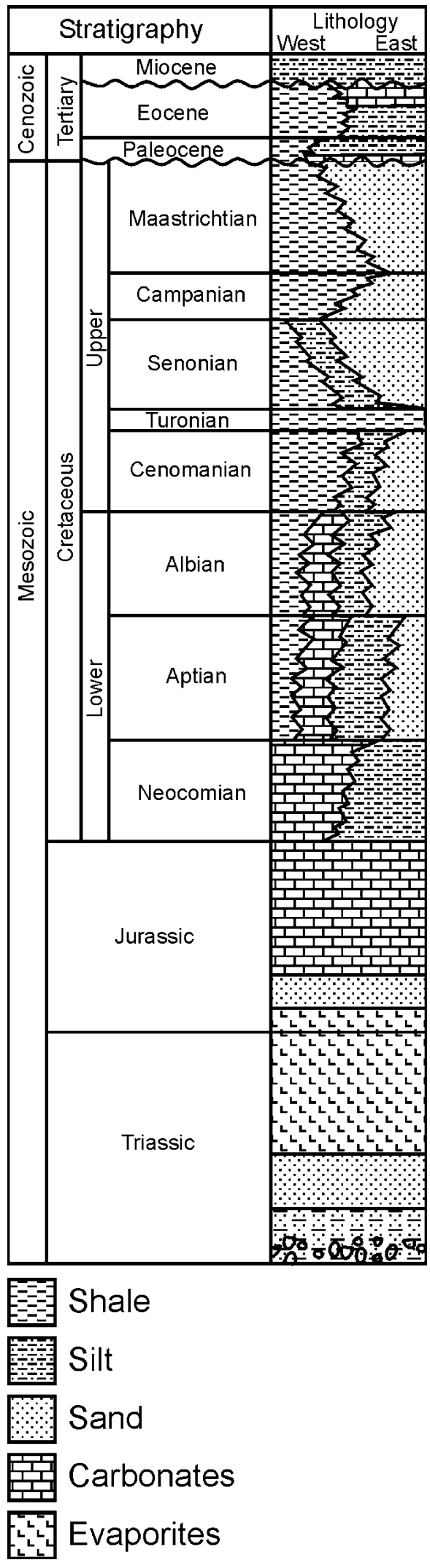

Fig. 3. Stratigraphic column illustrating the Mesozoic and Cenozoic stratigraphy of the Northern Subbasin (modified from Brownfield and Charpentier, 2003).
Tertiary clastic and carbonate rocks. The Upper Cretaceous and Tertiary mudstones act as the main seals for the reservoir units. Traps are a combination of structural closures and stratigraphic pinch-outs.

\section{2D Seismic data}

This study is based on interpretation of 2D seismic data from the Northern Subbasin of the Senegal Basin (Fig. 2a). The seismic interpretation has been carried out on 2D seismic data from the Rufisque Profond block west and southwest of Dakar (Fig. 2a), covering an area of approximately $3800 \mathrm{~km}^{2}$ and acquired with a line-spacing of $2-4 \mathrm{~km}$. The data image the seabed reflector as a trough-peak-trough reflection configuration that is best modelled with a $60^{\circ}$ rotated wavelet displayed at normal polarity. The vertical axis on all the seismic sections shown is two-way-travel-time (TWTT) and all structure maps shown also indicate TWTT. A velocity of $2500 \mathrm{~m} / \mathrm{s}$ has been used to convert TWTT to depth in metres.

\section{Description of enigmatic features in the Northern Subbasin}

A range of enigmatic features have been recognised and mapped from 2D seismic data in the Northern Subbasin, within a TWTT range of $1-2 \mathrm{~s}$ below the present-day seabed. This interval can be correlated with the Cenozoic and Paleogene interval. The recognised features include high amplitude anomalies, localised folds and eye-shaped structures (Fig. 2b). These features were only recently recognised and have not been penetrated by drilling. The lack of any well data to provide cuttings, core or wireline log data means that any interpretation of their origin must rely on detailed analysis of their geometrical characteristics, structural and stratigraphic context, and interrelationships. Once such information is compiled a comparison with similar features of known origin imaged by seismic data elsewhere should allow for their probable origin to be constrained.

In order to better illustrate the relative stratigraphic location of individual features correlation of the Oligocene unconformity (labelled OU in figures) from DSDP 367 into the study area has been attempted using a couple of long regional seismic lines. In the Rufisque Profond area the unconformity separates a package of high amplitude, largely continuous reflections from overlying less continuous, low to medium amplitude reflections, most likely representing Eocene carbonates and Miocene siltstones, respectively (Fig. 3). One additional key horizon (Horizon A) has been mapped across the Rufisque Profond area where the enigmatic features, described here in detail, are found (Fig. 4). Horizon A has been mapped as a reflection of opposite polarity to that of the seabed and with moderate to high amplitude. The horizon dips gently $\left(3^{\circ}\right)$ towards the west and it locally truncates underlying strata and is elsewhere seen to be onlapped by the overlying 


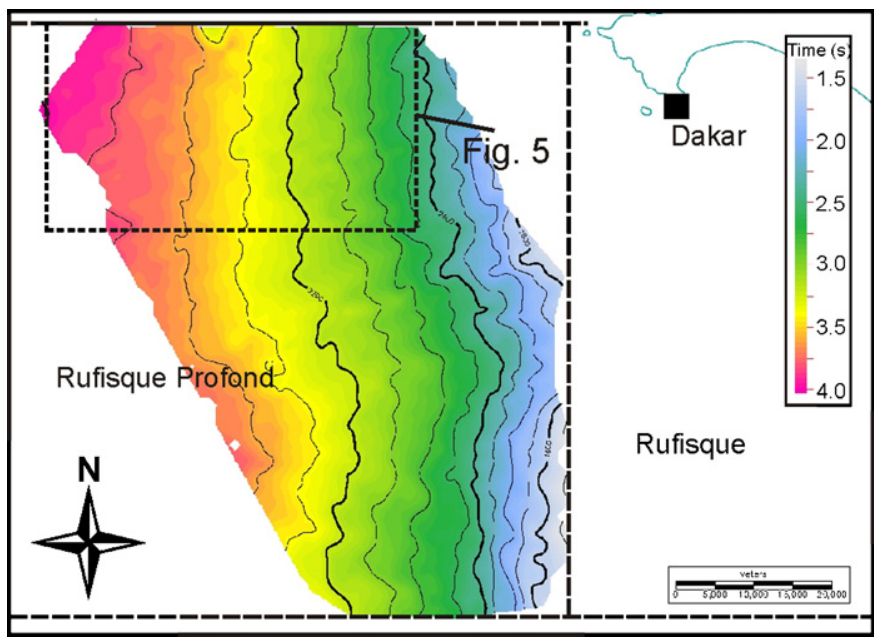

Fig. 4. Time-structure map of Horizon A mapped across the Rufisque Profond block. The horizon dips gently towards the west at approximately $3^{\circ}$. The horizon is interpreted to be of Miocene age. See Fig. $1 \mathrm{~b}$ for Rufisque Profond 2D seismic data outline.

strata. Horizon A overlies the correlated Oligocene unconformity and is interpreted to be Miocene in age.

\subsection{Discordant high-amplitude reflections}

More than 70 high amplitude discordant seismic reflection anomalies, exhibiting a peak-trough-peak reflection configuration, have been mapped in the northern part of the Rufisque Profond block of the Northern Subbasin (Fig. 2). The anomalies have been mapped using 2D seismic lines and from this their basic geometrical characteristics have been constrained within the $3 \mathrm{D}$ limitations offered by the grid of $2 \mathrm{D}$ seismic data.

Individual anomalies measure between $300 \mathrm{~m}$ and $10 \mathrm{~km}$ in lateral extent and where mapped on intersecting $2 \mathrm{D}$ seismic lines the ratio between the maximum and minimum lateral dimension does not exceed 3:1. The lack of 3D data means that the spatial connectivity of individual seismic anomalies is difficult to accurately constrain. However, the inability to map any anomaly laterally for more than $10 \mathrm{~km}$ and the clear termination of individual anomalies on seismic lines of varying orientation, strongly suggest that the anomalies are near-circular to slightly elongated in shape. Individual reflection anomalies have been found to transgress and cross-cut through as much as $350 \mathrm{~ms}$ TWTT of vertical section. Some anomalies also exhibit a concave upward geometry characterised by a near-central low flanked by gently inclined $\left(<10^{\circ}\right)$ transgressive edges, others appear to transgress in one direction only, whilst some are more flat-lying exhibiting only minor discordance often in the form of undulations or slightly upturned edges. Anomalies seen at different depths are sometimes clearly linked suggesting that groups of anomalies form a highly interconnected network both laterally and vertically.

The interpreted outline of 40 high amplitude anomalies mapped in the northern part of the Rufisque Profond area

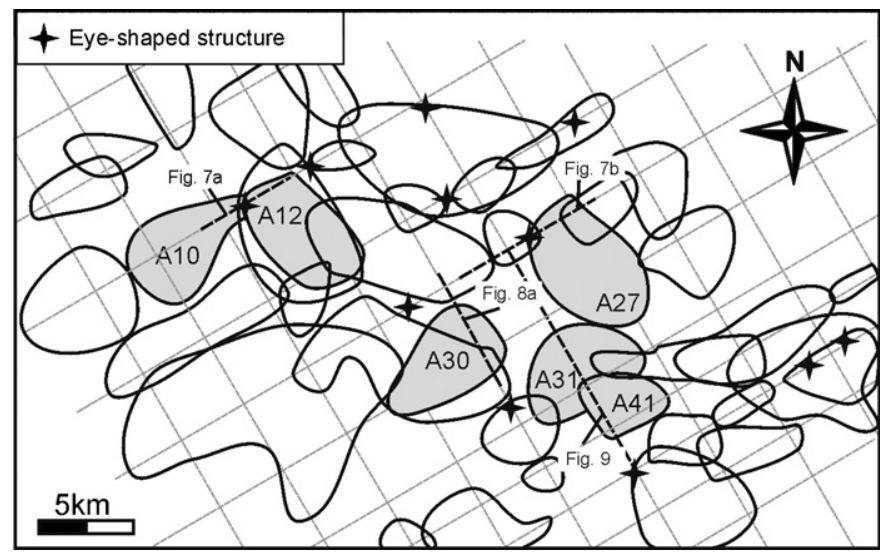

Fig. 5. Map showing the outline of 40 amplitude anomalies mapped within a $700 \mathrm{~km}^{2}$ area of the northern Rufisque Profond block. The anomalies are circular to slightly elongated in shape, cover areas of a few $\mathrm{km}^{2}$ and cover $>60 \%$ of the mapped area. Anomalies A10, A12, A27, A30, A31 and A41 mentioned in the text are highlighted in grey. Eleven eye-shaped structures have been mapped in the area and these are marked on the map. See Figs. 2 and 4 for map location.

is shown in Fig. 5. The map covers an area of around $700 \mathrm{~km}^{2}$ and has been compiled by mapping the extent of individual anomalies from 2D seismic lines. Each anomaly has been mapped on at least two intersecting lines, which allows for their likely 3D shape to be constrained. The anomalies appear as circular or slightly elongated bodies that cover areas of a few tens of $\mathrm{km}^{2}$ and form a highly complex planview geometry in which many of the anomalies are seen to overlap. Within the area shown $>60 \%$ is affected by anomalies.

Anomaly A10 is shown in Fig. 6 to illustrate many of the general characteristics exhibited by the anomalies. The anomaly has been confidently mapped on three intersecting 2D seismic lines (Fig. 6a) and based on this its overall geometry has been interpreted. The anomaly has a pearshaped plan-view outline with its long axis oriented NE-SW. It measures approximately $7 \mathrm{~km} \times 4 \mathrm{~km}$ and covers an area of about $20 \mathrm{~km}^{2}$. Towards the west, in particular, the edge of the anomaly clearly transgresses at an angle of approximately $8^{\circ}$, cross-cutting up through the surrounding stratal reflections (Fig. $6 \mathrm{~b}$ and c). The transgressive edges give the anomaly a slightly saucershaped geometry that exhibits a vertical relief of approximately $150 \mathrm{~ms}$ TWTT (Fig. 6a).

\subsection{Eye-shaped structures}

Distinctive eye-, and occasionally, cone-shaped structures have been identified above the seismic anomalies, approximately $1 \mathrm{~km}$ below the present-day seabed (Figs. $2 \mathrm{~b}$ and 7). These structures have not been found outside the area in which the anomalies have been identified. The eyeshaped structures are of limited size, measuring 500-1500 m in width and a few hundred metres in height (Fig. 7). None of these structures are located at the point of crossing between intersecting lines and as such their 3D geometry 

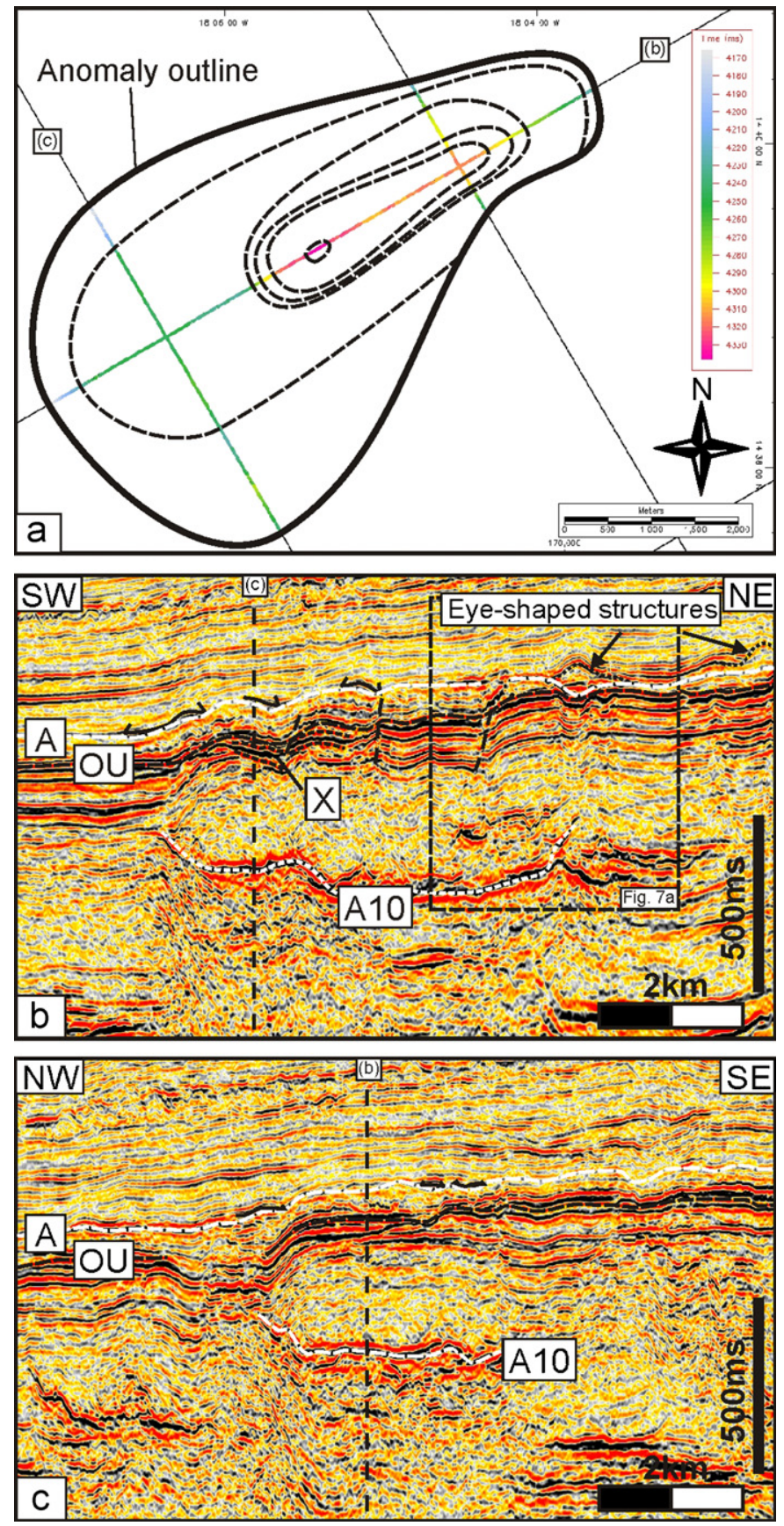

Fig. 6. (a) Time-structure map of anomaly A10 interpreted using three intersecting $2 \mathrm{D}$ seismic lines. The anomaly has a pear-shaped outline with the long axis oriented NE-SW and appears to adopt a somewhat bowlshaped 3D geometry. The anomaly measures approximately $7 \mathrm{~km} \times 4 \mathrm{~km}$ and covers an area of about $20 \mathrm{~km}^{2}$. (b) and (c) Intersecting 2D seismic sections showing the slightly upward concave cross-sectional geometry of A10. Towards the west the edge of the anomaly transgresses at an angle of approximately $8^{\circ}$, cross-cutting approximately $150 \mathrm{~ms}$ TWTT of vertical section. A number of SW dipping normal faults developed in the strata overlying the central and south-western part of anomaly A10 (b). The faults tip out upward at or below Horizon A and there is some evidence for thickening of strata across the most south-western fault (labelled X). OU marks an Oligocene (-Early Miocene) unconformity correlated from the DSDP 367 well. See Fig. 5 for location of A10. cannot be resolved with confidence. Almost all of the eyeshaped structures mapped are located at the same stratigraphic level, with Horizon A forming the basal surface to the structures (Fig. 7a). However, a small number of structures are found at slightly deeper (Fig. 7b) and shallower stratigraphic levels between Horizon A and the Oligocene unconformity. Where the internal structure of the eye-shaped structures is resolved it shows 1 or 2 flatlying to slightly convex upward seismic reflections that onlap onto the basal surface (Fig. 7). The surface that defines the top of the structures is convex-up exhibiting a relief of a few tens of metres and has a concordant or slightly divergent relationship with overlying stratal reflections. In some cases the stratal reflections immediately underneath the structures are downthrown along a set of inward dipping normal faults resulting in the development of a sag-like structure underlying the main part of the eye-shaped structures (Fig. 7).

Eleven eye-shaped structures have been interpreted above the high amplitude anomalies mapped in Fig. 5. They are spaced at $5-15 \mathrm{~km}$ and appear to be preferentially developed above the edges of underlying high amplitude anomalies. This latter observation is confirmed by vertical seismic sections. In Fig. 7a an eye-shaped structure measuring $950 \mathrm{~m}$ in width and approximately $90 \mathrm{~ms}$ TWTT in thickness is developed above the junction between anomaly A10 and anomaly A12 and in Fig. 7b a smaller eye-shaped structure measuring approximately $650 \mathrm{~m}$ in width and $70 \mathrm{~ms}$ TWTT in thickness is located directly above the transgressive tip of anomaly A27.

\subsection{Localised fold structures}

Locally, monoclinal and domal folds are developed at the level of Horizon A, clearly affecting Horizon A itself and the underlying stratigraphy (e.g Figs. $2 \mathrm{~b}$ and 6). In common with the eye-shaped features, these fold structures are only developed within the area where the high amplitude discordant anomalies are found. The fold shown in Fig. 8 is an example of a very well imaged structure found in the study area. It is approximately $2 \mathrm{~km}$ wide and has a structural relief of $100 \mathrm{~ms}$ TWTT at the level of Horizon A. The seismic reflections underlying Horizon A are concordant and also clearly folded. A number of onlapping reflections are seen within the unit downwards bound by Horizon A and upwards by the seismic reflection labelled Y. Of note is that on the seismic shown in Fig. 8a the width of the fold is almost perfectly coincident with the lateral extent of the underlying seismic anomaly A30. Deformation at the level of Horizon A is also seen above the western edge of anomaly A10 (Fig. 6b and c) where a series of monoclinal structures with a vertical relief of 50-100 ms TWTT are developed. On the NE-SW trending profile shown in Fig. $6 \mathrm{~b}$ the monoclinal structures appear to be associated with a number of SW dipping normal faults developed in the strata overlying the central and south-western part of anomaly A10, whilst on the NW-SE 

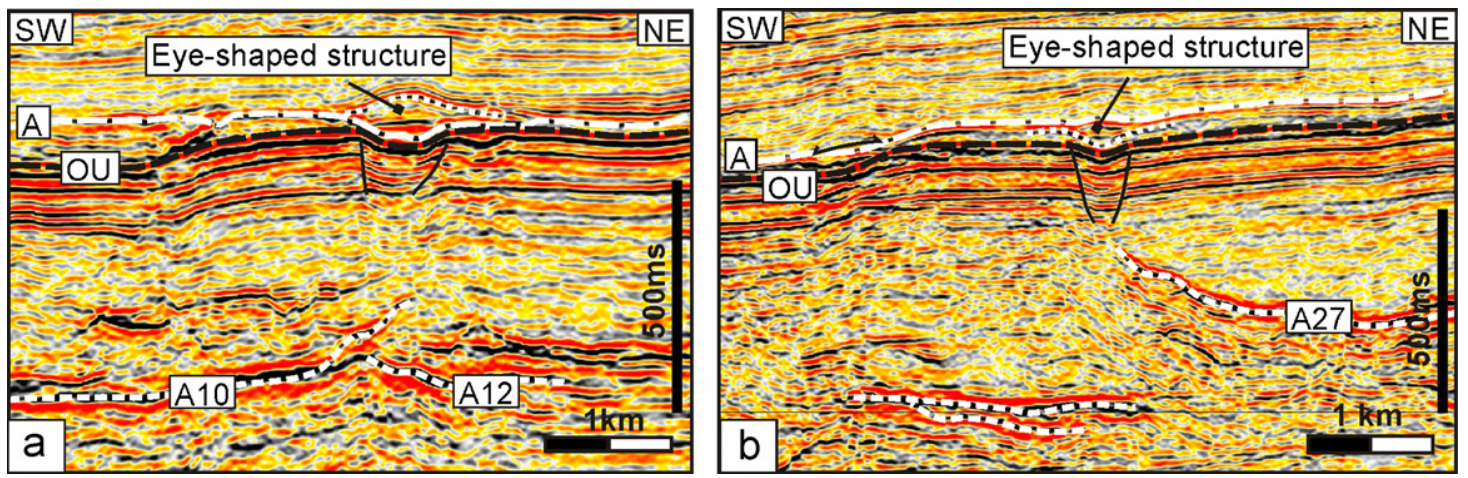

Fig. 7. Seismic sections illustrating the cross-sectional geometry of two eye-shaped structures located above the junction between anomalies A10 and A12 (a) and above the transgressive tip of A27 (b), respectively. The eye-shaped structures are seen near the level of Horizon A. Numerous eye-shaped structures have been mapped in the study area. They measure $500-1500 \mathrm{~m}$ in width and a few hundred metres in height. See Fig. 5 for line locations. OU marks an Oligocene (-Early Miocene) unconformity correlated from the DSDP 367 well.
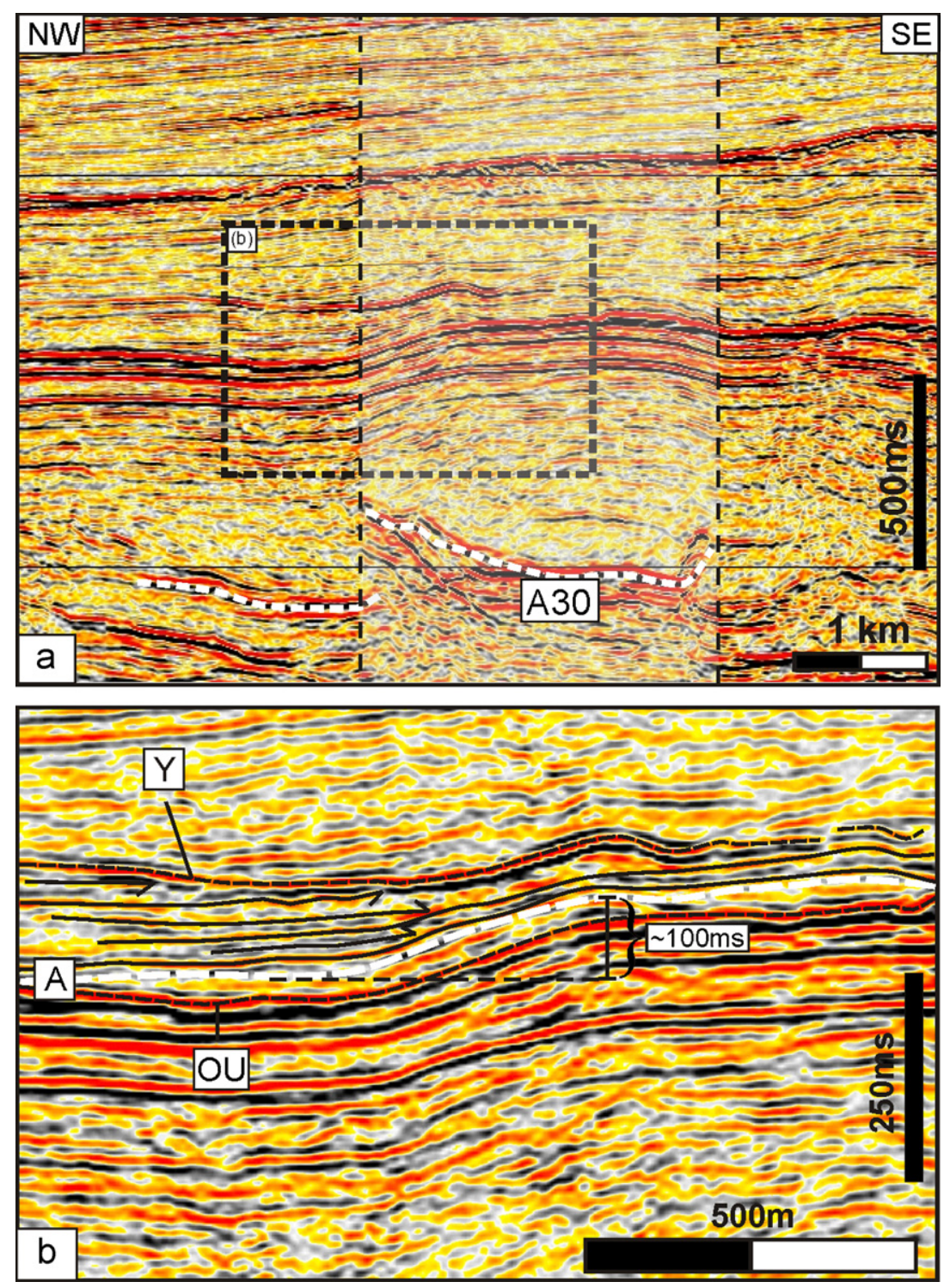

Fig. 8. (a) Seismic section showing the upward concave cross-sectional geometry of anomaly A30 and its clear spatial coincidence with a fold structure developed near the level of Horizon A. (b) Enlarged section showing a number of onlapping reflections above the north-western margin of anomaly A30, within the unit downwards bound by Horizon A and upwards by the seismic reflection labelled Y. The vertical relief across the forced is approximately $100 \mathrm{~ms}$ TWTT. OU marks an Oligocene (-Early Miocene) unconformity correlated from the DSDP 367 well. See Fig. 5 for line location. 
trending line shown in Fig. 6c the monocline is developed directly above the north-western tip of A10 and shows no apparent relationship with faulting. The faults tip out upward at or below Horizon A and there is evidence for thickening of strata across the most western fault (labelled $\mathrm{X}$ in Fig. 6b).

\section{Discussion}

\subsection{Interpretation of discordant seismic anomalies in the Northern Subbasin}

The discordant seismic anomalies imaged by $2 \mathrm{D}$ seismic data from the Northern Subbasin are found within the prospective section of the currently under-explored offshore Northern Subbasin of the Senegal Basin. Elucidating the origin of these features is of critical importance to future hydrocarbon exploration in the area. The two most likely origins of discordant, high amplitude reflections like the ones mapped in the Northern Subbasin are: (1) erosional (channels) or (2) intrusive (sand, salt or igneous).

\subsubsection{Erosional origin?}

The anomalies recorded on individual 2D seismic sections in the Northern Subbasin are imaged as high amplitude concave upward features that resemble the cross-sectional expression of erosional channel cuts (Fig. 2b). Erosional channels often appear on seismic data sets with varying dimensions, and displaying a discordant relationship with the surrounding strata. They can exhibit varying amplitude depending on the lithology and hence acoustic impedance of the channel fill (e.g. Posamentier, 2003; Abreu et al., 2003). The seismic anomalies in the Northern Subbasin were initially interpreted as channels, however, this interpretation is now considered unlikely for a number of reasons, including: (1) the 3D geometry of the anomalies, as it can be constrained from 2D seismic data, strongly suggests that individual anomalies are of limited lateral extent and circular to slightly elongated in shape with the long axes of individual anomalies showing no preferred strike orientation. This observation is incompatible with an interpretation of the anomalies as channels as these would be expected to be much more laterally continuous and show a preferred long axis orientation perpendicular to the strike of the paleo-slope. (2) In cases where the anomalies and their surrounding host-strata are well imaged (e.g. Fig. 9), individual stratal reflections can be correlated either side of the cross-cutting transgressive limbs of the anomalies (Fig. 9), indicating that the strata either side of the cross-cutting anomalies were originally laterally connected. This excludes an interpretation of the anomalies as erosional in origin as such an interpretation would suggest that the strata outside and within (channel fill) the concave up structures would be two different sedimentary packages. (3) Levees are not observed bounding the anomalies. This does not exclude an interpretation of the anomalies as channels, as levees may not always develop or be preserved, but their absence is notable.

\subsubsection{Intrusive origin?}

Three types of intrusion of material in a sedimentary section are considered: (1) sandstone intrusion as a result of remobilisation of sediment, often associated with overpressure and loading, (2) intrusive salt sheets and (3) saucer-shaped igneous intrusions. Salt diapirism has not been recognised in the Northern Subbasin (Brownfield and Charpentier, 2003), which makes an interpretation of the seismic anomalies as salt sheet intrusions unlikely. An interpretation of the anomalies as salt-related is further discarded based on geometrical differences between the seismic amplitude anomalies described here and intrusive salt sheets described in the literature (e.g. Talbot, 1993; Schultz-Ela and Jackson, 1996; Hudec and Jackson, 2006). In recent years both sandstone and igneous intrusions have been studied extensively from seismic data and their seismic and geometrical characteristics are now well constrained.

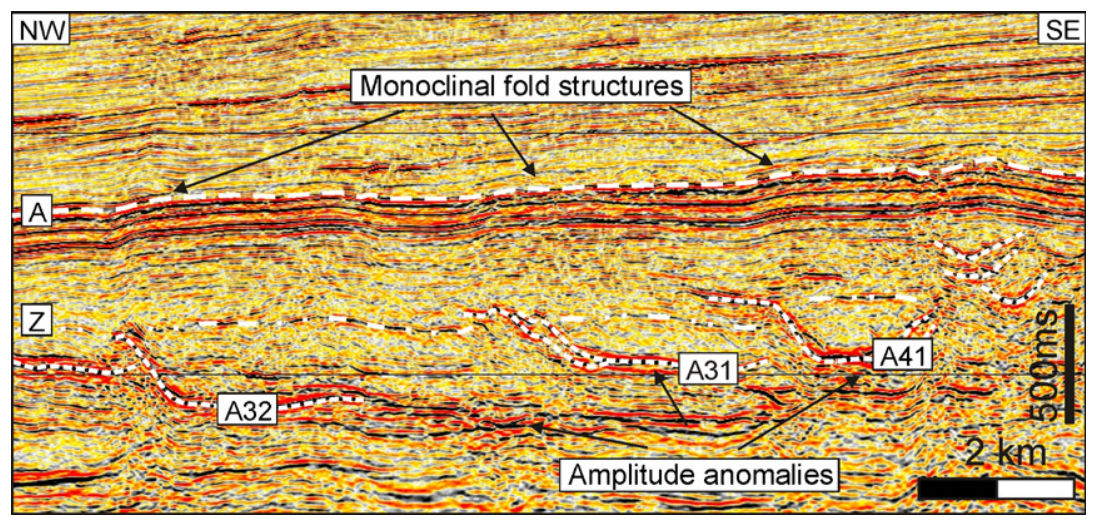

Fig. 9. Seismic section showing three northwestward transgressing discordant seismic anomalies A31, A32 and A41. A seismic reflection (labelled Z) has been mapped on the section and can be correlated either side of transgressive sections of the anomalies. This indicates that the strata either side of the cross-cutting anomalies are time equivalent and hence that the anomalies are secondary features that formed following the deposition of the sediments. Note the spatial coincidence between the northwestern transgressive segments of the three discordant anomalies and overlying monoclinal structures. See Fig. 5 for line location. 
These two types of intrusive bodies do share many similar characteristics, however, they can be distinguished by their geometrical attributes (Fig. 10) and interaction with their host-sediments.

Sandstone intrusions are found in many sedimentary basins worldwide. In Africa they are found onshore in Tabarka, Northern Tunisia (Huuse, pers. comm.), and pipelike sediment injection features have been interpreted on 3D seismic data from offshore West Africa (Davies, 2003). They are imaged on seismic data as discordant, moderate to high amplitude anomalies with dimensions ranging from 50 to $300 \mathrm{~m}$ in vertical relief, a few hundreds to a few kilometres in lateral extent and covering areas of hundreds of $\mathrm{m}^{2}$ to a few $\mathrm{km}^{2}$ (Huuse and Mickelson, 2004; Huuse et al., 2005; Huuse et al., 2007). They are typically 'V'-shaped or appear as 'wing'-like discordant edges emanating from concordant reflections in cross-section (Huuse et al., 2007). They have circular to oval to somewhat angular plan-view geometries and most terminate downward in discrete apexes, with only a minority terminating downwards at concordant amplitude anomalies (Huuse and Mickelson, 2004). The inclination of the anomalies relative to the host sediment typically ranges between $10^{\circ}$ and $40^{\circ}$ (Huuse and Mickelson, 2004; Huuse et al., 2005; Huuse et al., 2007).

Igneous sills are seismically imaged as high amplitude, discordant and continuous reflections that often abruptly terminate (Smallwood and Maresh, 2002; Hansen et al., 2004; Planke et al., 2005). They range in size from $\sim 1 \mathrm{~km}^{2}$ to $>100 \mathrm{~km}^{2}$ and in thickness from a few tens of centimetres to $>300 \mathrm{~m}$ (Hansen et al., 2004). In 3D many exhibit complex saucer-shaped geometries with edges that transgress at up to $20^{\circ}$ angles, in some cases crosscutting up to as much as $6.5 \mathrm{~km}$ of vertical section, but more commonly cross-cutting between $500 \mathrm{~m}$ and $2 \mathrm{~km}$ (Hansen et al., 2004; MaltheSørensen et al., 2004; Hansen and Cartwright, 2006b; Cartwright and Hansen, 2006), whilst others form more planar concordant or discordant bodies (Trude, 2004; Hansen et al., 2004; Hansen and Cartwright, 2006a).

Evidently, sandstone and igneous intrusions may appear very similar when imaged on $2 \mathrm{D}$ seismic, however, they differ in at least three discernable ways (Fig. 10): (1) sandstone intrusions are generally smaller (up to a few $\mathrm{km}^{2}$ ) than igneous intrusions (tens of $\mathrm{km}^{2}$ ), (2) sandstone intrusions commonly form ' $V$ '-shaped or 'wing'-like structures at the edges of concordant anomalies, whilst igneous intrusions form more upwardly curved concave shapes or planar transgressive sheets and (3) the inclined edges of sandstone intrusions $\left(10-40^{\circ}\right)$ are typically steeper relative to the hoststrata than those of igneous sills $\left(<20^{\circ}\right)$.

Comparing the geometrical characteristics and seismic character of the discordant seismic anomalies imaged in the Northern Subbasin with those of known sandstone intrusions and igneous sills, it is clear that they show a greater level of resemblance to igneous sills than sandstone intrusions. Most importantly they consistently exhibit the three characteristics that distinguish igneous sills from sandstone intrusions: (1) they cover large areas of a few tens of $\mathrm{km}^{2}$, (2) many are seen to adopt gently curved upward concave shapes and (3) the transgressive sections of the anomalies are found to transgress at $<10^{\circ}$.

\subsection{Interpretation of eye-shaped structures and localised folds in the Northern Subbasin}

The interpretation of the discordant seismic anomalies of the Northern Subbasin as igneous in origin is further

\begin{tabular}{|l|l|l|}
\hline & Sandstone intrusions & Saucer-shaped sills \\
\hline Shape & $\begin{array}{l}\text { V -shaped } \\
\text { Wing -like }\end{array}$ & Saucer-shaped \\
\hline Lateral extent & A few $100 \mathrm{~m}$ to a few $\mathrm{km}$ & A few $\mathrm{km}$ \\
\hline Area & $100 \mathrm{~m}^{2}$ to a few $\mathrm{km}^{2}$ & $\sim 1 \mathrm{~km}^{2}$ to $>100 \mathrm{~km}^{2}$ \\
\hline Vertical relief & $50-300 \mathrm{~m}$ & Up to $6.4 \mathrm{~km}$ (typically $500 \mathrm{~m}-2 \mathrm{~km}$ ) \\
\hline $\begin{array}{l}\text { Transgressive } \\
\text { angles }\end{array}$ & $10-40^{\circ}$ & $<20^{\circ}$ \\
\hline $\begin{array}{l}\text { Cross-sectional } \\
\text { appearance }\end{array}$ & \multicolumn{2}{|c|}{ "v"-structure } \\
\hline
\end{tabular}

Fig. 10. Comparison of general characteristics of sandstone and igneous intrusions. Sandstone intrusions are "V"'-shaped or "wing"-like, whilst igneous intrusions may adopt "saucer"-shaped geometries. Saucer-shaped sills tend to cover greater areas and exhibit greater vertical relief than sandstone intrusions. Both sandstone intrusions and saucer-shaped sills have discordant limbs, with the limbs of sandstone intrusions transgressing at $10-40^{\circ}$ as oppose to saucer-shaped sills that generally transgress at $<20^{\circ}$. 
supported by their spatial relationship with the lensoid or eye-shaped structures developed at or near Horizon A (Figs. 2b and 7). Igneous sills imaged along the NE Atlantic margin are often found to be associated with hydrothermal vents that develop at the seafloor at the time of intrusion (Svensen et al., 2004; Planke et al., 2005; Hansen, 2006). These vent structures may be either eyeshaped, conical or crater-like in cross-section, are circular in plan-view and have dimensions ranging between 500 and $3500 \mathrm{~m}$ in diameter and 50-640 $\mathrm{m}$ in height (Hansen, 2006). Hydrothermal vents develop above sill edges, crests in sills and occasionally above the upper tips of faults and at fault intersections (Planke et al., 2005; Hansen, 2006). The detailed plan-view geometry of the eye-shaped structures mapped in the Northern Subbasin cannot be constrained from the 2D seismic data. However, they are well imaged on $2 \mathrm{D}$ vertical sections and exhibit similar cross-sectional geometries and dimensions on both dip- and strike-lines suggesting that they may be circular in plan-view. They are consistently located above the edges of or crests on underlying discordant seismic anomalies and are limited in areal extent to the area where the anomalies are seen, clearly indicating a causative relationship between them. The dimensions of the eye-shaped structures mapped in the Northern Subbasin are comparable with those of hydrothermal vents in the NE Atlantic and an interpretation of these structures as hydrothermal vents hence seems fully supported by the available 2D seismic data.

Forced folds have been found to develop above both sandstone (Shoulders and Cartwright, 2004) and igneous (Trude et al., 2003; Hansen and Cartwright, 2006b) intrusions in order to compensate for the added thickness provided by the intruded material. In the study area, folding of strata immediately overlying some seismic anomalies has been recognised up to the level of or slightly above Horizon A (Figs. 6b, c, 8 and 9). Their clear spatial relationship with the seismic anomalies suggests that they are very likely to have developed due to forced folding during the intrusive process. Their presence does not preferentially support an interpretation of the intrusive as being igneous rather than clastic, however, their presence above the anomalies is fully compatible with the preferred interpretation of the discordant anomalies as igneous sills.

Faults are often developed as part of the forced folding process (Pollard and Johnson, 1973; Hansen and Cartwright, 2006b, 2007). Sandbox modelling of faulting associated with forced folds developed above laccoliths, suggests that the intrusion of igneous bodies should lead to the development of inward dipping reverse faults around the sill margin (Pollard and Johnson, 1973). However, evidence from 3D seismic data (Trude et al., 2003; Hansen and Cartwright, 2006b, 2007) suggests that such reverse faults are not always developed or simply not imaged by this type of data. In contrast, normal faults have been imaged above the crest and centre of sills on 3D seismic data and these faults have been interpreted to develop in order to accommodate the outer arc stretching of the forced fold (Hansen and Cartwright, 2006b, 2007). Hence, lack of reverse faults does not preclude an interpretation of the localised folds as forced folds. Possible interpretations of the fold-related normal faults that are imaged (Fig. 6) in the study area are that they are the result of arc stretching or compaction above the underlying sills. However, the possible growth wedge seen on the most western fault in Fig. 6b (marked X) suggests that this fault moved prior to the time represented by Horizon A, which is interpreted to mark the timing of intrusion (see Section 5.4 for further discussion), and hence that faulting predates intrusion.

The vertical relief on intrusion-related forced folds can be used as an estimate of the thickness of the underlying sills. In the Northern Subbasin the vertical relief measured on the interpreted forced folds is up to $100 \mathrm{~ms}$ TWTT, indicating sill thicknesses of up to approximately $125 \mathrm{~m}$ (assuming a sediment velocity of $2500 \mathrm{~m} / \mathrm{s}$ ). In many cases there is no forced folds developed or the relief on these folds is very subtle, suggesting that the majority of the sills are thin (less than $125 \mathrm{~m}$ thick).

\subsection{Interpretation pitfall— "soft" sills?}

One characteristic of the anomalous reflections that requires further discussion is the polarity. Most of the anomalies, when compared with the response from the seabed (positive acoustic impedance boundary) in the area, display a "soft" response, which would normally be taken to indicate that the composition of the intruded material is of lower velocity and/or density than the host lithology. This acoustic response is not readily explained by an interpretation of the anomalies being of igneous origin, as this lithology would be higher in density and velocity compared to the clastic host lithology and hence be expected to result in a "hard" acoustic response. Similar unexpected reverse responses have been observed on 2D seismic data from the Norwegian Margin and FaeroeShetland Basin, where several discordant seismic anomalies have been drilled and the presence of igneous intrusions is well established (e.g. Skogly, 1998; Planke et al., 2005).

Smallwood and Maresh (2002) suggested that "soft" sills may arise due to certain stacking patterns of sills and other possible explanations include silic or high vesicular igneous composition (Smallwood and Kirk, 2006), phase rotation of the seismic wavelet and tuning effects when imaging thin sills. The assumption above has been that the seabed is correctly imaged, which is not necessarily the case (Smallwood, pers. comm.) and this should ideally be verified by examination of positive impedance boundaries in the subsurface imaged by the seismic data.

Seismic wavelet extraction using Schlumberger IESX software indicates a dominant frequency of $25-30 \mathrm{~Hz}$ in the intruded interval corresponding to a tuning thickness $(\lambda / 4)$ of approximately $50 \mathrm{~m}$ and a thickness of separability $(\lambda / 2)$ of around $100 \mathrm{~m}$ (assuming a sill velocity of $5550 \mathrm{~m} / \mathrm{s}$; cf. Skogly, 1998). Comparing these values with the estimate of sill thickness of less than $125 \mathrm{~m}$ obtained from the 
vertical relief on intrusion-related forced folds suggests that the top and base of individual sills will rarely be fully resolved by the seismic data and hence interference between the sill top and base reflections is likely to be a common phenomena in the study area.

The seismic expression of such thin sills is illustrated with reference to Fig. 11 . The seabed wiggle best resembles a $60^{\circ}$ rotated Ricker wavelet displayed at normal polarity. A comparable response is seen at a high amplitude reflection approximately $1 \mathrm{~km}$ below the seabed interpreted to arise from the top of the Eocene carbonate series (Fig. 11a). This indicates limited, if any, rotation of the wavelet in the seabed to top carbonate interval. Below the top carbonate reflection a discordant high amplitude anomaly interpreted as a sill is seen and this sill exhibits the peak-trough-peak wiggle configuration characteristic of the sills mapped across the study area. Detailed inspection of the seismic response along the sill locally shows a slight positive excursion within the negative central trough (Fig. 11a). Using realistic parameters extracted from the seismic data and the published literature (see Fig. 11b caption for summary) the seismic response from a high velocity wedge (sill) surrounded by lower velocity material (sediment) has been modelled (Fig. 11b). The model shows
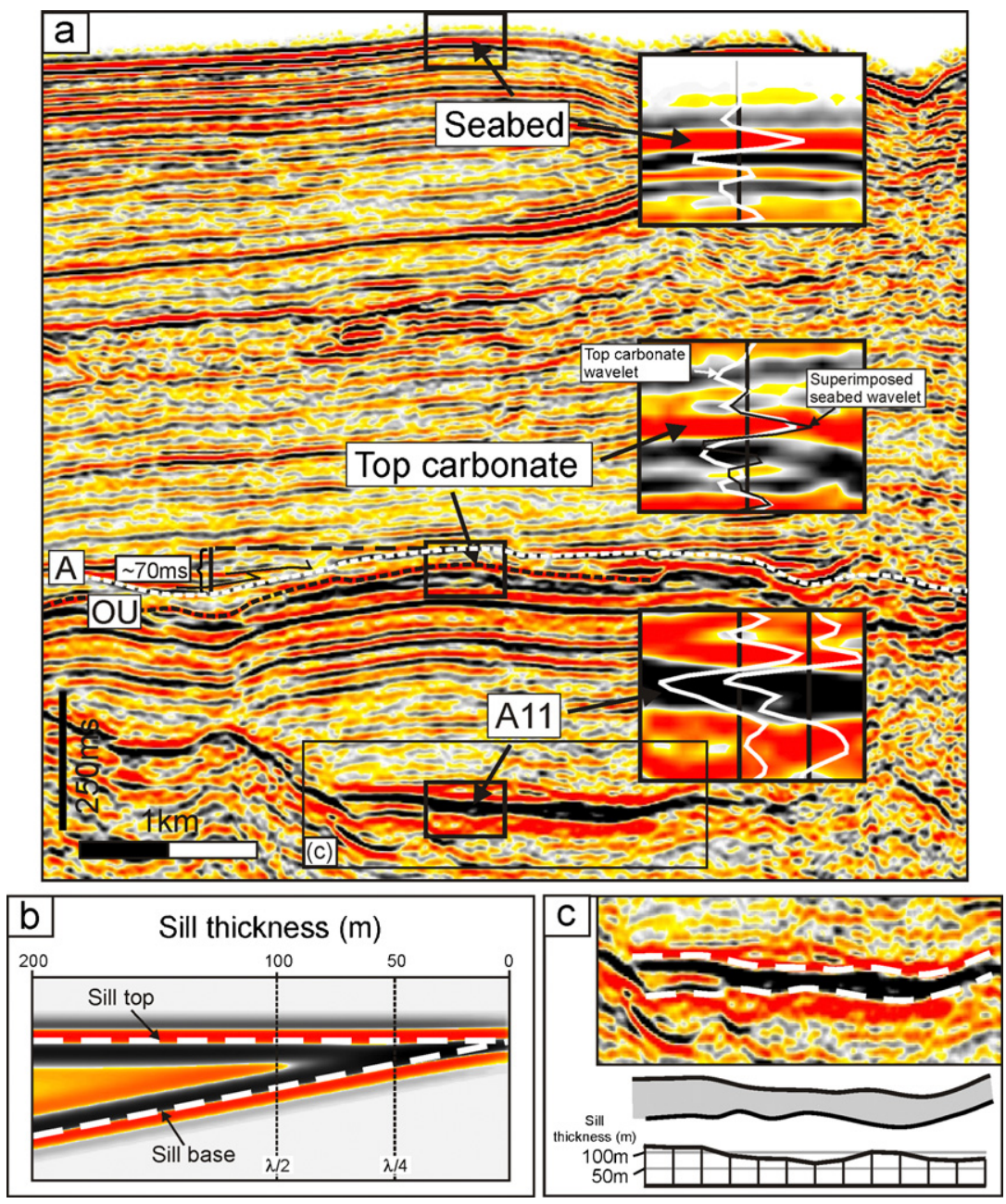

Fig. 11. (a) Seismic section showing the seismic response from the seabed, the probable top of the Eocene carbonate unit and a high amplitude anomaly A11 interpreted as a sill. The seabed is imaged as a trough-peak-trough reflection configuration best described as a $60^{\circ}$ rotated Ricker wavelet that is displayed using normal polarity. The wavelet response from the interpreted top of the Eocene carbonate unit is very similar to that from the seabed suggesting only very limited rotation of the wavelet. The interpreted sill gives rise to a peak-trough-peak reflection configuration that is opposite to the seabed and top carbonate responses. Note onlap onto Horizon A above the southwestern margin of anomaly A11 and the vertical relief of 70 ms TWTT (approximately equivalent to $100 \mathrm{~m}$ ) measured across the forced fold developed above the anomaly. OU marks an Oligocene (-Early Miocene) unconformity correlated from the DSDP 367 well. See Fig. 2 for line location. (b) Seismic wedge model (courtesy of M. Szuman) showing a relatively high velocity $\left(V \mathrm{p}=5550 \mathrm{~m} / \mathrm{s}(\right.$ Skogly, 1998$) ; V \mathrm{~s}=0.3818 V \mathrm{p}+0.8727 \approx 2120 \mathrm{~m} / \mathrm{s}$ (Smallwood and Maresh, 2002) and density $\left(\rho=2.84 \mathrm{mg} / \mathrm{m}^{3} ; \mathrm{Skogly}, 1998\right)$ wedge of material representing an igneous sill tapering from 0 to $200 \mathrm{~m}$ in thickness encased within a lower velocity $(V=2500 \mathrm{~m} / \mathrm{s})$ and density $\left(\rho=2.60 \mathrm{mg} / \mathrm{m}^{3}\right)$ host sediment. A $27 \mathrm{~Hz}, 60^{\circ}$ rotated Ricker wavelet was used in the seismic modelling. The model shows that sill thinner than approximately $90 \mathrm{~m}$ will be imaged by the seismic data as an overall peak-trough-peak reflection configuration due to interference between the top and base sill reflections. (c) Interpretation of the top and base of the sill and calculation of sill thickness. The sill varies in thickness between 60 and $110 \mathrm{~m}$ (assuming a velocity of the igneous material of $5550 \mathrm{~m} / \mathrm{s})$, which corresponds well with the estimate of sill thickness $(\sim 100 \mathrm{~m})$ calculated from the vertical relief on the forced fold developed above the sill. 
that a sill that is less than approximately $90 \mathrm{~m}$ thick will give rise to a seismic response characterised by an overall peak-trough-peak configuration comparable to the response imaged by the Senegal seismic data. Using the modelling results the top and base of the sill imaged in Fig. 11a have been mapped and conversion of the obtained thickness of the sill from TWTT to meters suggests that the sill varies in thickness from approximately $60-100 \mathrm{~m}$ (Fig. 11c) with the thinnest parts of the sill being imaged as a peak-trough-peak configuration and the thicker parts of the sill $(\sim 90-110 \mathrm{~m})$ exhibiting a reflection configuration best described as peak-trough-peak-trough-peak as predicted by the wedge model. The calculated thickness of the sill corresponds reasonably well with the thickness that can be estimated from the vertical relief on an overlying forced fold (Fig. 11a) which indicates a maximum thickness of approximately $90 \mathrm{~m}$. The slight discrepancy between the two sill thickness calculations may be related to erosion across the crest of the forced fold, error in the velocity estimate for the sediments and/or igneous material or relate to the depth of the intrusion below the contemporaneous seabed (cf. Hansen and Cartwright, 2006b).

The preferred explanation for the "soft" appearance of sills imaged by 2D seismic data from offshore Senegal is hence that the majority of sills are thin $(<90 \mathrm{~m})$ and hence their seismic response is affected by interference between the seismic response from the top and base of the sills.

\subsection{Timing and origin of igneous activity in the Northern Subbasin}

Recently, a new method for constraining the timing of igneous intrusive events from seismic data, independent of radiometric dating of the intruded material itself, has been proposed and widely applied along the NE Atlantic Margin (Davies et al., 2002; Trude et al., 2003; Svensen et al., 2004; Planke et al., 2005; Hansen, 2006; Hansen and Cartwright, 2006b). The method relies on the application of seismic-stratigraphic principles, to define the position of hydrothermal vent structures and intrusion-related forced folds, and provides an excellent and simple method for dating individual intrusive events and their relative timing. Hydrothermal vents and intrusion-related forced folds are developed at the seabed at the time of intrusion and hence their bounding surfaces mark the timing of the intrusive event.

Interestingly, Horizon A forms the base to the majority of the interpreted hydrothermal vent structures (Fig. 7) and also marks the approximate upward bounding surface to the intrusion-related forced folds (Fig. 8). This suggests near coeval intrusive activity across the study area around the time represented by the age of Horizon A. Correlation with the regional stratigraphy, although not well defined due to lack of well control in the studied area, suggests that Horizon A is of Miocene age and hence the igneous activity can be constrained to the Miocene.
Along the Senegalese margin and close to the studied area, evidence of Miocene igneous activity is clearly documented in the Cap-Vert peninsula where the outcropping Oligocene to Recent suites of volcanic rocks have been dated by radiometric methods (Crevola et al., 1994). Offshore, the Cayar seamount, which is located in the northern part of the offshore Northern Subbasin (Fig. 2a and $b$ ), has previously been interpreted on seismic data and the interpretation suggests that it was emplaced prePliocene, mainly during the Miocene (Bellion and Crevola, 1991). The apparent time equivalence between the intrusion of igneous sills in the Rufisque Profond block, the emplacement of volcanic rocks in the Dakar Peninsula and the development of the Cayar Seamount suggests that the Northern Subbasin was influenced by a significant phase of igneous activity during the Miocene. Miocene igneous activity has also been recognised further a field in the CapeVerde Islands (Fig. 1a), located approximately $500 \mathrm{~km}$ west of Dakar (Mitchell et al., 1983; Courtney and White, 1986; Bellion and Crevola, 1991; Patriat and Labails, 2006).

Three main stages of igneous activity are recognised in the Senegalese part of West Africa. The two early stages during the Triassic-Jurassic and mid-late Cretaceous are related to the rifting of the South Atlantic and subsequent modification of plate motions, respectively (Bellion and Crevola, 1991). The latest stage of igneous activity (Tertiary-Quaternary) has been linked to reactivation of old zones of weakness in the form of rift-related MidJurassic basement faults and renewed magma (formed as a result of rising astenospheric material melted by adiabatic pressure release; Liégeois et al., 2005) expulsion in response to collisional events between Africa and Europe in the Mediterranean area (Bellion and Crevola, 1991; Liégeois et al., 2005). This hypothesis is supported by evidence indicating a spatial relationship between structural features and magmatism (Bellion and Crevola, 1991; Liégeois et al., 2005). Previously published work suggests that Cenozoic magmatism occurred in the Senegal Basin and throughout NW Africa discontinuously from the Oligocene up to the Quaternary, with peak activity in the Miocene (Bellion and Crevola, 1991). The intrusion of the igneous sills described here and the development of the Cayar Seamount belong to this latter phase of magmatism and it is interpreted that their formation was related to collision between the African and European plates.

The Cape-Verde Islands are the sealevel expression of a large crustal feature forming a topographic bulge 4-500 km across, often referred to as the Cape-Verde Rise, (Stillman et al., 1983; Mitchell et al., 1983; Courtney and White, 1986; Patriat and Labails, 2006) most likely related to hotspot activity (Courtney and White, 1986; Carracedo et al., 1998), but alternatively suggested to be a consequence of tectonics between the African and European plates (Patriat and Labails, 2006). The simultaneous igneous activity in the Cape-Verde Islands and NW Africa, including Senegal, possibly indicates a common origin of the Miocene igneous activity and it has been suggested that both are related to 
reactivation of old fault zones as a result of plate collision in the Mediterranean (Liégeois et al., 2005). Alternatively, it should be considered if a Cape-Verde hot-spot could be responsible for the igneous activity observed in the Senegal Basin. The Cape-Verde Rise is centred underneath the easternmost islands of the Cape-Verde archipelago and extends approximately $250 \mathrm{~km}$ towards the east (Courtney and White, 1986; Patriat and Labails, 2006). It does not extend into the study area where igneous intrusion have been interpreted, suggesting that there is no link between a Cape-Verde hot-spot and igneous activity offshore and onshore Senegal. It is possible that the basement bulge was bigger in the past and extended further east. However, the occurrence of widespread Miocene igneous activity across NW Africa shortly after the initiation of Africa-Europe plate collision at ca. $38 \mathrm{Ma}$ and a probable link between structural features and igneous activity further supports the interpretation that the Senegalese igneous activity is related to plate collision.

\subsection{Implications}

The most important result of this work is the identification of significant shallow-level igneous activity in a hydrocarbon prone under-explored sedimentary basin on the Atlantic Margin offshore West Africa. The presence of igneous sills in the Northern Subbasin may indicate that intrusions of a similar age are present within other currently poorly explored sedimentary basins along the West African margin, as a probable result of the collision between Africa and Europe.

Recognising and constraining the timing of shallow-level igneous intrusive bodies in sedimentary basins is critical in relation to any hydrocarbon exploration and development activities. Intrusion of hot magma and the initiation of hydrothermal systems introduce a major heat source into a sedimentary basin. This supplied heat may induce early maturation of hydrocarbons (Raymond and Murchison, 1988, 1991; Didyk and Simoneit, 1989; Kennish et al., 1992; Svensen et al., 2004). The width of the hydrothermal aureole and thus the volume of heat-affected host-rock surrounding a sill from which hydrocarbons may be produced is approximately twice the thickness of the sill (Raymond and Murchison, 1991; Svensen et al., 2004). However, the circulation of hydrothermal fluids means that not only the host sediments immediately surrounding individual intrusions are affected, but any sandstone units with reservoir potential found within the affected area may have been indurated by the hydrothermal fluids. The intrusive event is also likely to be coincident with increased heat flow within the basin as a whole.

Hydrothermal vent structures formed above sills may have reservoir potential as some of these are likely to be composed of remobilised sand (Svensen et al., 2003; Jamtveit et al., 2004; Hansen, 2006). However, the fluid that leads to the entrainment of the sediments found within such vents is hydrothermal in origin, and normally supersaturated, and the vent sediments are hence likely to be cemented. On the Norwegian Margin conduits that connect hydrothermal vents to the underlying sill complex have been found to act as fluid conduits long after (up to as much as $50 \mathrm{My}$ ) hydrothermal activity has ceased (Svensen et al., 2003). Hence, their most important implication for petroleum systems may be as migration pathways for hydrocarbons.

Intrusion-related forced folds represent potential hydrocarbon traps, forming four-way dip closures (Hansen and Cartwright, 2006b). If sandstone units are folded as part of the deformation process these structures have the potential to form hydrocarbon traps that may subsequently be charged. However, the level of cementation by hydrothermal fluids is critical in relation to the preserved reservoir potential in these overlying folded units, and it may be that the best play potential related to these structures is found in post-intrusion deep-water clastics that pinch-out against the folds rather than within the folded strata.

\section{Conclusions}

1. The Cretaceous sediments of the northern part of the offshore Northern Subbasin of the Senegal Basin are locally intruded by igneous sills. There is no indication that the southern part of the offshore Northern Subbasin is affected by any intrusive igneous event. This could indicate that the source of the magma is to the north where the contemporaneous Cayar Seamount is located.

2. Hydrothermal vents and intrusion-related forced folds are found associated with the interpreted igneous sills and interpretation of their stratigraphic context constrains the timing of intrusion to the Miocene. The intrusive event is coincident in time with the development of the Cayar Seamount and emplacement of volcanic rocks in the Dakar peninsula suggesting more widespread igneous activity in the area during the Miocene than previously reported.

3. The Miocene igneous event in the offshore part of the Northern Subbasin is most likely to be related to vertical magma migration along re-activated basement structures, probably as a result of collision between Africa and Europe.

4. The interpretation suggests a period of higher heat flow during the Miocene, which may have had an impact on wider source rock maturity in the subbasin. Circulation of hydrothermal fluids following intrusion is likely to have affected reservoir units and have influenced fluid migration pathways within the basin.

5. The sills interpreted from the seismic data give rise to an unexpected, apparent "soft" seismic response when compared with other positive impedance contrasts in the seismic data such as the seabed and the top of Eocene carbonate unit. The preferred explanation for the "soft" appearance of sills is that the majority of sills 
are thin $(<90 \mathrm{~m})$ and hence their seismic appearance is affected by interference between the seismic response from the top and base of the sills. The limited thickness of the sills is supported by thickness estimates derived from the vertical relief on forced folds developed above some of the intrusions.

6. The forceful intrusion of igneous sills has produced forced folds forming potential four-way-dip traps in the overlying section and potential stratigraphic traps in the form of pinch-out of post-intrusion deep-water clastics against the folds.

\section{Acknowledgements}

We are thankful to Petrosen and Edison International for release of proprietary 2D seismic data and to Schlumberger GeoQuest for providing seismic interpretation software. Magda Szuman is thanked for providing the seismic wedge model and Myron Thomas is thanked for providing comments on an early version of the manuscript. John Smallwood is thanked for yet another thorough and constructive review. Thanks are also due to an anonymous reviewer.

\section{References}

Abreu, V., Sullivan, M., Pirmes, C., Mohrig, D., 2003. Lateral accretion packages (LAPs): an important reservoir element in deep water sinuous channels. Marine and Petroleum Geology 20, 631-648.

Bellion, Y., Crevola, G., 1991. Cretaceous and cainozoic magmatism of the Senegal Basin (West Africa): a review. In: Kampunzu, A.B., Lubala, R.T. (Eds.), Magmatism in Extensional Structural Setting; the Phanerozoic African Plate. Springer, Berlin, pp. 189-208.

Brownfield, M.E., Charpentier, R.R., 2003. Assessment of the undiscovered oil and gas of the Senegal Province, Mauritania, Senegal, The Gambia, and Guinea-Bissau, Northwest Africa. US Geological Society Bulletin 2207-A.

Carracedo, J.C., Day, S., Guillou, H., Badiola, E.R., Canas, J.A., Torrado, F.J.P., 1998. Hot-spot volcanism close to a passive continental margin: the Canary Islands. Geological Magazine 135, 591-604.

Cartwright, J.A., Hansen, D.M., 2006. Magma transport through the crust via interconnected sill complexes. Geology 34, 929-932.

Courtney, R.C., White, R.S., 1986. Anomalous heat flow and geoid across the Cape Verde Rise: evidence for dynamic support from a thermal plume in the mantle. Geophysical Journal of the Royal Astronomical Society $87,815-867$.

Crevola, G., Cantagrel, J.-M., Moreau, C., 1994. Le volcanisme Cénozoïque de la presqu'île du Cap Vert (Sénégal): cadre chronologique et géodynamique. Bulletin de la Societé Géologique de France $165,437-466$.

Davies, R.J., 2003. Kilometer-scale fluidization structures formed during early burial of a deepwater slope channel on the Niger Delta. Geology 31, 949-952.

Davies, R., Bell, B.R., Cartwright, J.A., Shoulders, S., 2002. Threedimensional seismic imaging of Paleogene dike-fed submarine volcanoes from the northeast Atlantic margin. Geology 30, 223-226.

Didyk, B.M., Simoneit, B.R.T., 1989. Hydrothermal oil of Guaymas Basin and implications for petroleum formation mechanisms. Nature $342,65-342$.

Hansen, D.M., 2006. The morphology of intrusion-related vent structures and their implications for constraining the timing of intrusive events along the NE Atlantic Margin. Journal of the Geological Society, London 163, 789-800.

Hansen, D.M., Cartwright, J.A., 2006a. Saucer-shaped sill with lobate morphology revealed by 3D seismic data: implications for resolving a shallow-level sill emplacement mechanism. Journal of the Geological Society, London 163, 509-523.

Hansen, D.M., Cartwright, J., 2006b. The three-dimensional geometry and growth of forced folds above saucer-shaped igneous sills. Journal of Structural Geology 28, 1520-1525.

Hansen, D.M., Cartwright, J., 2007. Reply to comment by K. Thomson on "The three-dimensional geometry and growth of forced folds above saucer-shaped sills" by D.M. Hansen and J. Cartwright. Journal of Structural Geology 29, 741-744.

Hansen, D.M., Cartwright, J.A., Thomas, D., 2004. 3D seismic analysis of the geometry of igneous sills and sill junction relationships. In: Davies, R.J., Cartwright, J.A., Stewart, S.A., Lappin, M., Underhill, J.R. (Eds.), 3D Seismic Technology: Application to the Exploration of Sedimentary Basins, Geological Society, London, Memoirs 29, pp. 199-208.

Hudec, M.R., Jackson, M.P.A., 2006. Advance of allochthonous salt sheets in passive margins and orogens. American Association of Petroleum Geologists Bulletin 90, 1535-1564.

Huuse, M., Mickelson, M., 2004. Eocene sandstone intrusions in the Tampen Spur area (Norwegian North Sea Quad 34) imaged by 3D seismic data. Marine and Petroleum Geology 21, 141-155.

Huuse, M., Cartwright, J.A., Gras, R., Hurst, A., 2005. Kilometre-scale sandstone intrusions in the Eocene of the Outer Moray Firth (UK North Sea): migration paths, reservoirs and potential drilling hazards. In: Doré, A.G., Vining, B. (Eds.), Petroleum Geology: Northwest Europe and Global perspectives - Proceedings of the Sixth Petroleum Conference, Geological Society, London, pp. 1577-1594.

Huuse, M., Cartwright, J., Hurst, A., Steinsland, N., 2007. Seismic characterization of large-scale sandstone intrusions. In: Hurst, A., Cartwright, J. (Eds.), Sand Injectites: Implications for Hydrocarbon Exploration and Production. AAPG Memoir 87.

Jamtveit, B., Svensen, H., Podladchikov, Y.Y., Planke, S., 2004 Hydrothermal vent complexes associated with sill intrusions in sedimentary basins. In: Breitkreuz, C., Petford, N. (Eds.), Physical Geology of High-Level Magmatic Systems, Geological Society, London, Special Publications 234, pp. 233-241.

Kennish, M.J., Lutz, R.A., Simoneit, B.R.T., 1992. Hydrothermal activity and petroleum generation in the Guaymas Basin. Reviews in Aquatic Sciences 6, 467-477.

Liégeois, J.-P., Benhallou, A., Azzouni-Sekkal, A., Yahiaoui, R., Bonin, B., 2005. The Hoggar swell and volcanism: reactivation of the Precambrian Tuareg shield during Alpine convergence and West Africa Cenozoic volcanism. In: Foulger, G.R., Natland, J.H., Presnall, D.C., Anderson, D.L. (Eds.), Plates, Plumes and Paradigms. Geological Society of America, Special Paper, vol. 388, pp. 379-400.

Malthe-Sørensen, A., Planke, S., Svensen, H., Jamtveit, B., 2004. Formation of Saucer-Shaped Sills, Geological Society, London, Special Publication 234, pp. 215-227.

Mitchell, J.G., Le Bas, M.J., Zielonka, J., Furnes, H., 1983. On dating the magmatism of Maio, Cape Verde Islands. Earth and Planetary Science Letters 64, 61-76.

Patriat, M., Labails, C., 2006. Linking the Canary and Cape-Verde hot-spots, Northwest Africa. Marine Geophysical Researches 27, 201-215.

Planke, S., Rasmussen, T., Rey, S.S., Myklebust, R., 2005. Seismic characteristics and distribution of volcanic intrusions and hydrothermal vent complexes in the Vøring and Møre Basins. In: Doré, A.G., Vining, B. (Eds.), Petroleum Geology: Northwest Europe and Global perspectives-Proceedings of the Sixth Petroleum Conference, Geological Society, London, pp. 833-844.

Pollard, D.D., Johnson, A.M., 1973. Mechanics of growth of some laccolithic intrusions in the Henry Mountains, Utah, II: bending and failure of overburden layers and sill formation. Tectonophysics 18 , 311-354. 
Posamentier, H.W., 2003. Depositional elements associated with a basin floor channel-levee system: case study from the Gulf of Mexico. Marine and Petroleum Geology 20, 677-690.

Raymond, A.C., Murchison, D.G., 1988. Development of organic maturation in the thermal aureoles of sills and its relation to sediment compaction. Fuel 67, 1599-1608.

Raymond, A.C., Murchison, D.G., 1991. The relationship between organic maturation, the widths of thermal aureoles and the thickness of sills in the Midland Valley of Scotland and Northern England. Journal of the Geological Society, London 148, 215-218.

Schultz-Ela, D.D., Jackson, M.P.A., 1996. Relation of subsalt structures to suprasalt structures during extension. American Association of Petroleum Geologists Bulletin 80, 1896-1924.

Shoulders, S.J., Cartwright, J., 2004. Constraining the depth and timing of large-scale conical sandstone intrusions. Geology 32, 661-664.

Skogly, O.P., 1998. Seismic characterisation of and emplacement of intrusives in the Vøring Basin. M.Sc. Thesis, University of Oslo, Norway.

Smallwood, J., Kirk, W.J., 2006. Paleocene exploration in the FaroeShetland Channel: disappointments and discoveries. In: Doré, A.G., Vining, B. (Eds.), Petroleum Geology: Northwest Europe and Global perspectives-Proceedings of the Sixth Petroleum Conference, Geological Society, London, pp. 977-991.

Smallwood, J.R., Maresh, J., 2002. The properties, morphology and distribution of igneous sills: modelling, borehole data and 3D seismic from the Faroe-Shetland area. In: Jolley, D.W., Bell, B.R. (Eds.), The North Atlantic Igneous Province: Stratigraphy, Tectonic, Volcanic and
Magmatic Processes, Geological Society, London, Special Publication, 197, pp. 271-306.

Stillman, C.J., Furnes, H., Le Bas, M.J., Robertson, A.H.F., Zielonka, J., 1983. The geological history of Maio, Cape Verde Islands. Journal of the Geological Society 139, 347-361.

Svensen, H., Planke, S., Jamtveit, B., Pedersen, T., 2003. Seep carbonate formation controlled by hydrothermal vent complexes: a case study from the Vøring Basin, Norwegian Margin. Geo-Marine Letters 23, 351-358.

Svensen, H., Planke, S., Malthe-Sørensen, A., Jamtveit, B., Myklebust, R., Eidem, T.R., Rey, S.S., 2004. Release of methane from a volcanic basin as a mechanism for initial Eocene global warming. Nature 429, $542-545$.

Talbot, C.J., 1993. Spreading of salt structures in the Gulf of Mexico. Tectonophysics 228, 151-166.

Thomson, K., Hutton, D., 2004. Geometry and growth of sill complexes: insights using 3D seismic from the North Rockall Trough. Bulletin of Volcanology 66, 364-375.

Trude, K.J., 2004. Kinematic indicators for shallow level igneous intrusion from 3D seismic data; evidence of flow direction and feeder location. In: Davies, R.J., Cartwright, J.A., Stewart, S.A., Lappin, M., Underhill, J.R. (Eds.), 3D Seismic Technology: Application to the Exploration

of Sedimentary Basins, Geological Society, London, Memoirs, 29, pp. 209-217.

Trude, K.J., Cartwright, J.A., Davies, R.J., Smallwood, J.R., 2003. A new technique for dating igneous sills. Geology 31, 813-816. 